\title{
The Influence of Price, Service Quality, and Promotion Against Decision Users Transportation Online (Grab) in Jakarta
}

\author{
Gregorius Widiyanto') \\ gregorius.widiyanto@ubd.ac.id \\ Pujiarti $\left.{ }^{2}\right)$ \\ pujiarti.pujiarti@ubd.ac.id \\ Fx.Pudjo Wibowo ${ }^{3)}$ \\ fx.wibowo@ubd.ac.id \\ 1) 2)3)Buddhi Dharma University
}

\begin{abstract}
The purpose of this research is to see price, service quality, and promotion partially (individually) or simultaneously (jointly) against the decisions of online transportation service users (Grab) in Jakarta. The research was conducted by spreading questionnaires, while the research method was using Simple Random Sampling. The independent variables in this study are price, service quality, and promotion, while the dependent variable in this study is the decision of online transportation service users (Grab) in Jakarta. The analysis method used is direct questionnaire analysis. Online transportation service users (Grab) in Jakarta are 300 online Grab service users in Jakarta. The analytical method used in this study uses the coefficient of determination analysis, multiple regression analysis of the $F$ test and $t$ test, using SPSS Version 25 which is based on data from online Grab transportation service users of 300 people. The $t$ test shows that the price variable (X1) partially has a positive and significant effect (the $t$ count of price is $2,452>t$ table 1,65 and $0,015<0,05$ ) on decisions of online transportation service users (Grab) in Jakarta. Service quality (X2) partially has a positive and significant effect (the $t$ count of service quality is $9,286>t$ table 1,65 and $0,000<0,05$ ) on the decision of online transportation service users (Grab) in Jakarta. Promotion variable (X3) partially positive and significant effect (the $t$ count of promotion is $5,431>t$ table 1,65 and $0,000<0,05$ ) on the decision of users of online transportation services (Grab) in Jakarta. The F test results obtained the $F$ count is 72,020 with a significance value is 0,000 so that the value of $\mathrm{F}$ count $>\mathrm{F}$ table or $72,020>3,87$ or the level of significance (sig) $0,000<0,05$, it can be shown that the effect is simultaneously (together) between price, service quality, and Decision Users Transportation Online (Grab) in Jakarta and the R Square in this study means that variance in decision making can be taken by price, service quality, and promotion through a model of $42,2 \%$ and the remaining $57,8 \%$ comes from other variables excluding price, service quality, and promotion variables.
\end{abstract}

Keywords: Price, Quality of Service, Promotion, Decisions Users Transportation Online (Grab) 


\section{INTRODUCTION}

The development of the era of globalization which is increasingly rapid nowadays has caused an increase in population. This causes public demand and supply of needs to continue to increase. Apart from the need for clothing, food, and shelter, it turns out that the need for means of transportation is also a basic need in daily life. Therefore, in addition to carrying private vehicles, public transportation is also in demand by the public so it is not surprising that many public transports line the roads. However, society realizes that this is not relative and time efficient for some people.

This is used by service companies considering the increasingly advanced technology today, namely the development of gadgets. Therefore, service companies think of ways to take this opportunity and find online transportation that is channeled through drivers spread across Indonesia, in addition to getting profit opportunities, these service companies also make it easier for people to get transportation media and make time efficient at a relatively low cost. The increasing number of companies of this kind has led to competition between various online transportation service companies so that various ways are issued by companies to attract consumers. The impact of this competition results in decreased or increased consumer demand in choosing purchasing decisions from each company. Consumers prioritize price, service quality, and good promotion so that companies are trying to find a strategy, this is expected to gain new customers and retain existing customers to increase profitability(Hernawan and Andy 2018).

The problems that occur in purchasing decisions for online transportation services are relatively cheap prices with the best service quality that are needed to attract consumers. However, the lower the price, the lower the profits the company gets. The increase in online transportation prices due to increasing demand can also make consumers turn to other service companies along with the increase in population and the increasing human need for transportation equipment that is increasingly shifting from existing public transportation. It is appropriate for the online transportation service company to get an advantage but provide a price that is in accordance with what is given so that both parties get the same return.

Decisions of online transportation service users are influenced by the quality of services, the more the quality of services provided, the more comfortable consumers use these transportation services(Andy 2016). Online transportation companies compete in providing the best possible quality of service to attract their consumers, usually the quality of service provided is such as giving free masks to consumers and headgear to be protected(Hernawan and Andy 2019). In addition, the company provides criticism and suggestions for users who face problems with drivers which will be processed as soon as possible for the convenience of its consumers. The existence of consumer dissatisfaction with the quality of online transportation services reduces the integrity of the company. Therefore, service quality is very important to the decision of users of online transportation services.

Increasingly tighter competition to attract online transportation service purchasing decisions to consumers in choosing one company has caused competitors to start to come up with several new strategies. One of the strategies is promotion. Promotion is one important strategy and the most appropriate way to attract target 
consumers in various fields including services. In this case the promotion used is in the form of several promotions such as new users who are free to use online transportation, discounted prices, rewards from points that consumers get for use, getting free coupons when inviting colleagues to use these transportation, as well as several other strategies that attract consumers. This makes it possible to attract consumers in considering decision options for transportation use.

\section{FORMULATION OF THE PROBLEM}

The formulation of the problem in this study is

1. Does the price have a significant effect on the decision of online transportation service users (Grab) in Jakarta?

2. Does service quality have a significant effect on the decision of online transportation service users (Grab) in Jakarta?

3. Does promotion have a significant effect on the decision of online transportation service users (Grab) in Jakarta?

4. Are price, service quality, and promotion simultaneously and influential significant to the decision of online transportation services (Grab) in Jakarta?

\section{RESULTS AND DISCUSSION}

In this study, the authors took online transportation service users (Grab) in Jakarta as many as 300 people to be sampled in answering statements regarding the effect of price, service quality, promotion, and decisions users of online transportation services (Grab).

\section{Classical Regression Assumption Test Results}

\section{a. Normality Test}

This study uses a normal probability plot to test the normality if the spread of data (points) around the diagonal axis and follows the direction of the diagonal line.

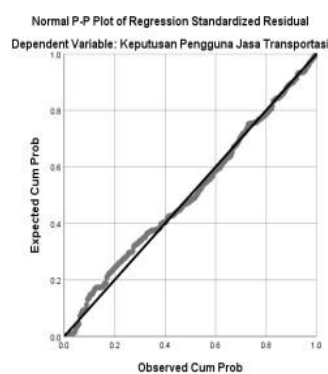

Picture 1.

Chart P. Plot Graph

Figure 1. shows the data spread around a diagonal line and following the direction of the diagonal line or Histogram graph, so that the data can be inferred it shows a normal distribution pattern. Hence it fulfills the assumptions normality.

\section{b. Multicollinearity Test}

The Multicollinearity test of this study uses the Tolerance and Variance Inflation Factor (VIF), where the low Tolerance value is the same as the value high VIF. This 
study uses a cutoff value of Tolerance $>0,10$ or equal with a VIF value $<10$ (Ghozali 2006, 91). Multicollinearity test results the regression model of this research is as follows:

Table 1.

Multicollinearity Test Results

\begin{tabular}{|l|r|c|}
\hline Variabel & Tolerance & VIF \\
\hline Value $(\mathrm{X} 1)$ & .869 & 1.150 \\
\hline Service quality $(\mathrm{X} 2)$ & .820 & 1.220 \\
\hline Promotion $(\mathrm{X} 3)$ & .844 & 1.185 \\
\hline
\end{tabular}

Source : Results of SPSS Version 25 Data Processing

Table 1. explains that the results of the calculation of the VIF (Variance Inflation Factor) value of each independent variable in this model are below 10 and the Torerance value is above $10 \%(0,10)$.

\section{c. Autocorrelation Test}

Based on the results of the SPSS output regression equation in this study where the D-W (Durbin-Watson), amounting to 2.096, for the dL value is 1.738 and the $\mathrm{dU}$ value is 1.7152 , then the $4-\mathrm{dU}$ value $=2.2848$ and $4-\mathrm{dL}=2.3663$, It can be concluded that the regression model above does not have autocorrelation problems.

\section{d. Heteroscedasticity Test}

Done to test whether in a regression model, there is an inequality of the variance of the residuals from one observation to another. Detection of the presence or absence of heteroscedasticity is done by looking at the presence or absence of a certain pattern on the scatterplot graph between SRESID and ZPRED.

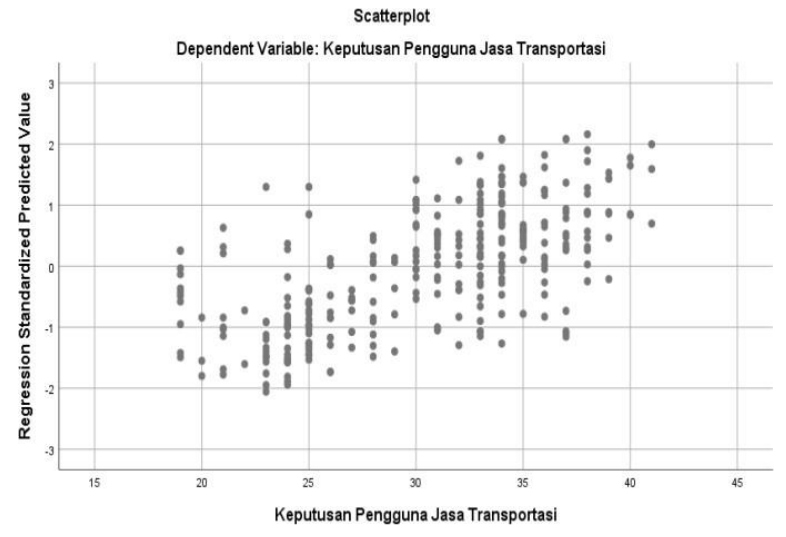

Picture 2.

Chart Scatterplot

Picture 2 that the dots generated randomly spread out and do not form a certain pattern or line trend. This means that the data is spread above and below the number 0 so that this model is free from heteroscedasticity problems. 


\section{Multiple Linear Analysis}

To determine whether there is a relationship between variable $\mathrm{X} 1$ (price), variable $\mathrm{X} 2$ (service quality), and variable $\mathrm{X} 3$ (promotion) to $\mathrm{Y}$ (decision of online transportation service users (Grab), and to measure the strength of this relationship, multiple regression analysis is used. with the calculation of SPSS (Statistical Package Service Softition) Version 25.

Table 2.

Multiple Regression Calculation Results

\begin{tabular}{|c|r|r|r|}
\hline \multicolumn{1}{|c|}{ Variabel } & \multicolumn{2}{|l|}{$\begin{array}{l}\text { Coefficient } \\
\text { Regression }\end{array}$} & Sig \\
\hline Constant & 8.321 & 5.142 & .000 \\
\hline Price $\left(\mathrm{X}_{1}\right)$ & .086 & 2.452 & .015 \\
\hline Service Quality $\left(\mathrm{X}_{2}\right)$ & .350 & 9.286 & .000 \\
\hline Promotion $(\mathrm{X} 3)$ & .214 & 5.431 & .000 \\
\hline F Count $: 72.020$ & & & \\
Sig $: 0.000$ & & & \\
\hline $\mathrm{R}^{2}: 0.422$ & & & \\
\hline $\mathrm{R}$ & & & \\
\hline
\end{tabular}

Source : Results of SPSS Version 25 Data Processing

Based on table 2 above, a multiple regression equation can beformed:

$$
Y=8,321+0,086 X 1+0,350 X 2+0,214 X 3+e
$$

a. A constant of 8,321 shows that if price (X1), service quality (X2), and promotion (X3) are considered constant, but are influenced by variables outside the model, it is estimated that the decision of online transportation services (Grab) in Jakarta (Y) will experience an increase of 8,321 .

b. The price regression coefficient $(\mathrm{X} 1)$ is 0,086 , which means that the price increases by one unit, then the decision of online transportation services (Grab) in Jakarta will increase by 0.086 , assuming other variables have a fixed value.

c. The service quality regression coefficient (X2) is 0,350 , which means that service quality increased by one unit, then the decision of online transportation services (Grab) in Jakarta will increase by 0,350 , assuming other variables have a fixed value.

d. The promotion regresssion coefficient $(X 3)$ is 0,214 , which means that promotion increases by one unit, then the decision of online transportation services (Grab) in Jakarta will increase by 0,214 , assuming other variables have a fixed value. 
Tabel 3.

\section{Coefficients $^{\mathrm{a}}$}

\begin{tabular}{|c|c|c|c|c|c|c|c|c|}
\hline & & $\begin{array}{l}\text { Unstanc } \\
\text { d } \\
\text { Coeffi }\end{array}$ & $\begin{array}{l}\text { rdize } \\
\text { ents }\end{array}$ & $\begin{array}{c}\text { Standar } \\
\text { dized } \\
\text { Coeffic } \\
\text { i ents }\end{array}$ & $\mathrm{t}$ & Sig. & Collinearity & tatistics \\
\hline & & B & $\begin{array}{l}\text { Std. } \\
\text { Error }\end{array}$ & Beta & & & Tolerance & VIF \\
\hline 1 & (Constant) & 8.321 & 1.618 & & 5.142 & .000 & & \\
\hline & Value & .086 & .035 & .116 & 2.452 & .015 & .869 & 1.150 \\
\hline & $\begin{array}{l}\text { Qualit } \\
\text { y } \\
\text { Serviv } \\
\text { e }\end{array}$ & .350 & .038 & .453 & 9.286 & .000 & .820 & 1.220 \\
\hline & Promotion & .214 & .039 & .261 & 5.431 & .000 & .844 & 1.185 \\
\hline
\end{tabular}

Dependent Variable : Decision Users Transportation Service Online (Grab)

a. Variabel price $(X 1)$ is partially positive and significant $(t$ count $2,452>\quad t$ tables $1,65$ and $0,015<0,05)$ against decision users transportation services online (Grab) in Jakarta.

b. Variabel service quality (X 2) is partially positive and significant ( $t$ count 9,286 > $\mathrm{t}$ tables 1,65 and $0,000>0,05)$ against decision users transportation services online (Grab) in Jakarta.

c. Variabel promotion (X3) is partially positive and significant $(\mathrm{t}$ count 5,431 > t tables 1,65 and 0,000>0,05) against decision users transportation services online (Grab) in Jakarta.

\section{F Test}

Tabel 4.

ANOVAa

\begin{tabular}{ll|r|r|r|r|c}
$\begin{array}{l}\text { Mode } \\
1\end{array}$ & $\begin{array}{r}\text { Sum of } \\
\text { Squares }\end{array}$ & $\begin{array}{l}\text { D } \\
\text { f }\end{array}$ & $\begin{array}{l}\text { Mean } \\
\text { Square }\end{array}$ & F & Sig. \\
\hline 1 & Regression & 4014.961 & 3 & 1338.320 & $\begin{array}{l}72.02 \\
0\end{array}$ & $\begin{array}{l}.000 \\
\mathrm{~b}\end{array}$ \\
\cline { 2 - 8 } & Residual & 5500.426 & 296 & 18.583 & & \\
\cline { 2 - 8 } & Total & 9515.387 & 299 & & & \\
\hline
\end{tabular}

a. Dependent Variable : Decision Users Transportation Service Online (Grab)

b. Predictors: (Constant), Price, Service Quality, Promorion

From the results of the $F$ test, the results obtained for $F$ count 72,020 with a significance value of 0,000 so that the $F$ count $>F$ table or $72,020>3,87$ or the significance level ( $\mathrm{sig}$ ) $0,000<0,05$, it can be concluded that it has an effect 
simultaneously (together equally) between price, service quality, and promotion against decision users transportation services online (Grab) in Jakarta.

\section{Test The Coefficient of Determination $\left(\mathbf{R}^{2}\right)$}

Tabel 5.

\begin{tabular}{ll|r|r|r} 
& \multicolumn{4}{c}{ Model Summary } \\
Model & R & R Square & $\begin{array}{c}\text { Adjusted } \\
\text { R Square }\end{array}$ & $\begin{array}{r}\text { Std. Error of } \\
\text { the Estimate }\end{array}$ \\
\hline 1 & $.650^{\mathrm{a}}$ & .422 & .416 & 4.311 \\
\hline
\end{tabular}

a. Predictors: (Constant), Promotion, Price, Quality of Service

b. Dependent Variable: Decision of On Line Transportation Service Users

Based on calculations with SPSS for window R Square in this study means that the variation in decision users services transportation online (Grab) in Jakarta can be explained by price, service quality, and promotion through the model by $42,2 \%$ and the remaining $57,8 \%$ derived from other variables outside the variables price, service quality, and promotion.

\section{BIBLIOGRAPHY}

Ardanis Fitri Pitaloka. 2015. Effect of Quality Service, Price, and Promotion of Sales Online Shop Clothing Muslim In Shafira Surabaya.Thesis, School of High Studies of Economics Indonesia (STIESIA) Surabaya

Andy. 2016. "Pengaruh Brand Image Dan Pelayanan Terhadap Loyalitas Pelanggan Pada PT. Budidaya Bahari Caksana Tangerang." Journal of Economics and Business Aseanomics (JEBA) 1(1).

Ghozali, Imam. 2010. Application of Multivariate Analysis with SPSS. Publisher Agency of Diponegoro University Semarang

Hernawan, Eso, and Andy. 2018. "Faktor Yang Mempengaruhi Keputusan Pembelian Konsumen Gerai Alfamidi Taman Royal Tangerang." Primanomics : Jurnal Ekonomi Dan Bisnis - Vol. 16. No. 3 (2018) 3:1-8.

Hernawan, Eso, and Andy. 2019. "Analisis Faktor- Faktor Yang Mempengaruhi Pelanggan Gojek Dan Grab Online Di Jakarta." Jurnal Ekonomi Dan Bisnis - Vol. 17. No. 1 (2019) 17(1):1-13.

Hardiansyah. 2011. Public Service Quality : Concept, Dimensions, Indicators, and Implementation. Yogyakarta : Gava Media

Hesti, Ratnaningrum. 2016. Effect of Promotion, Price, and Quality of Product Against Decision Purchase Consumer in Purchasing Materials Fuel Oil Type Pertalite in Yogyakarta. Thesis, University of Sanata Dharma Yogyakarta

Januar Efendi Panjaitan. 2016. Effect of Quality of Services Against Satisfaction Customer at JNE Branch Bandung. De Re Ma, Journal of Management, Vol. 11, No. 2, September 2016, 1-25 
Judge N. Maulana Dzikril. 2016. Effect of Quality of Service, Price, Location and Campaign Against Decision Purchase in SAS Café Resto Surabaya. Thesis, School of High Studies of Economics Indonesia (STIESIA) Surabaya

Kotler, Philip. 1998. Management Marketing : Analysis, Planning, Implementation, and Control, Edition Revised, Edition Indonesian. Prentice Hall

Kotler, Philip and Kevin Lanne Keller. 2012. Management Marketing, Issue 13 (Edition Translation) Volume 1. Jakarta: Erland

Lupiyoadi. 2001. Service Marketing Management Theory and Practice. Jakarta : Salemba Empat

Muslichah Erma Widiana. 2010. Marketing Management, First Printing. Publisher Karya Putra Darwati, Bandung

Nardiman, Yasri Hasim. 2015. Effect of Price, Promotion, and Quality of Service Against Satisfaction and Its Impact on Loyalty Customer Adira Finance in The District Kinali District Pasaman Barat. Journal of Research Management Business and Public, ISSN : 2337-5345, Program of Study Magismer Management Faculty of Economics, Padang State University, 1-20

Rambat, Lupiyoadi, and A. Hamdani. 2012. Service Marketing Management, Second Edition, Jakarta : Salemba Empat

Sugiyono. 2011. Quantitative Research Methods, Qualitative, and R \& D. Bandung : Alfabeta

Tri Retno Setiowaty, Winarningsih. 2017. Effect of Price, Quality Care, and Promotion Against Decision Purchase Consumer, Journal of Science and Research Management, Vol. 6, No. 4, April 2-017, ISSN 2461-0593, 1-15

Tjiptono, Fandy. 1997. Strategic Marketing, Edition Second, Molds Sixth. Publisher Andi Offset, Yogyakarta

V. Wiratna Sujarweni . 2015. Business and Economic Research Methodology. Yogyakarta : Pustaka Baru Press

Wahyu Nurul Faroh. 2017. Analysis of Effect of Price, Promotion, and Service Against Decision Purchase (Study of Marketing Online Through Networking Social Facebook "Care Face"). Creative, Journal of Scientific Study Program Management of the University of Pamulang, Vol. 4 No. 2 April 2017, 1-22 